\title{
Biodegradation of Petroleum Compound Using Pseudomonas aeruginosa
}

\author{
K. V. Darsa', A. Joseph Thatheyus ${ }^{2}$ \\ ${ }^{1}$ PG Department of Immunology and Microbiology, The American College, Madurai, India \\ ${ }^{2}$ PG \& Research Department of Zoology, The American College, Madurai, India \\ Email: jthatheyus@yahoo.co.in
}

Received 16 May 2014; revised 26 June 2014; accepted 16 August 2014

Copyright (C) 2014 by authors and OALib.

This work is licensed under the Creative Commons Attribution International License (CC BY). http://creativecommons.org/licenses/by/4.0/

(c) $\underset{\mathrm{EY}}{\mathrm{B}}$ Open Access

\begin{abstract}
The present study was conducted to determine the biodegradation of petrol by Pseudomonas aeruginosa isolated from petrol contaminated soil. The isolated strain was able to grow in minimal broth along with $2.5 \%, 5 \%, 7.5 \%$ and $10 \%$ concentrations of petrol which indicated the capability of the organism in degrading petrol and utilizing it as a source for growth. The isolated strain's efficiency was determined by analyzing the parameters $\mathrm{pH}$, optical density and $\mathrm{CO}_{2}$ released during petrol degradation. High Performance Liquid Chromatography (HPLC) analysis also confirmed the degradation of petrol by Pseudomonas aeruginosa.
\end{abstract}

\section{Keywords}

Biodegradation, Hydrocarbons, Pseudomonas aeruginosa, Petrol

Subject Areas: Environmental Sciences, Microbiology

\section{Introduction}

Petroleum-based products are the major source of energy for industry and daily life. Leaks and accidental spills occur regularly during the exploration, production, refining, transport and storage of petroleum and petroleum products. The amount of natural crude oil seepage was estimated to be 600,000 metric tons per year with a range of uncertainty of 200,000 metric tons per year [1]. Polycyclic Aromatic Hydrocarbons (PAHS) are important pollutants which are introduced into the environment through different ways such as anthropogenic activities, combustion, undesirable discharging of oil tankers, spills around petroleum refineries and gas plant facilities [2][4]. Hydrocarbons are considered to be of biological origin, since short and long chain hydrocarbons (alkanes: C10 - C20; C20 - C40) appear to be exclusively the origin of biological processes [5]. These compounds have toxic, carcinogenic and mutagenic properties [6] [7] and are considered as a serious hazard to human health and environment [8]-[12]. The use of microorganisms to reduce petroleum pollution through bioremediation has 
been shown to be a viable, relatively low cost, low-tech approach and is more widespread than chemical and physical treatments [13].

There has been extensive evidence on microbial degradation of petroleum hydrocarbons [14]. Since the biodegradation of petroleum hydrocarbons is a natural process controlled by temperature, $\mathrm{pH}$ and the scarcity of nutrients such as $\mathrm{N}$ and $\mathrm{P}$ [15] [16], bioremediation is a viable and promising method for clean-up and remedy of hydrocarbon polluted environment [17].

Bacteria are the most active agents in petroleum biodegradation and there is evidence of their fundamental role as primary degraders of spilled oil [18]-[20]. Effect of various nutrients on the degradation of crude oil by different bacteria was investigated by several scientists [21]-[23]. Several factors, both physico-chemical and biological, affect the rate of microbial degradation of hydrocarbons in soil. Recently, growing interest in the use of several Pseudomonads during degradation of crude oil have been reported [24]-[28]. However, application of statistical experimental design for optimization of crude oil degradation with Pseudomonas sp. was rarely investigated. Recently, medium optimization for a novel crude-oil degrading lipase from Pseudomonas aeruginosa SL-72 using statistical approaches for bioremediation of crude-oil was reported [29].

ZoBell [30] reported that nearly hundred species of bacteria, representing thirty microbial genera, had hydrocarbon oxidizing properties. Many species and genera had been found to have this ability [31]. The heterotrophic microorganisms found in the soil include naturally occurring populations that have the ability to degrade petroleum products species of Pseudomonas, Arthrobacter, Alcaligenes, Corynebacterium, Flavobacterium, Achromabacter, Micrococcus, Nocardia, and Mycobacterium appear to be the most consistently isolated hydrocarbon degrading bacteria from soil [32]. The present work is designed to isolate bacterial strain capable of degrading oil contaminants and to test its efficiency of petrol degradation.

\section{Materials and Methods}

For isolating efficient petrol degrading bacterial strain, soil samples were collected from petrol bunks and automobile workshops around Madurai in sterile containers and brought to the laboratory immediately [33]. Such soil samples were subjected to serial dilution upto $10^{-7}$ dilution [34]. From $10^{-5}$ and $10^{-6}$ dilution, $0.1 \mathrm{ml}$ was taken and spread plated on Bushnell Hass mineral salt medium (Magnesium sulphate $0.2 \mathrm{~g}$, Calcium chloride $0.02 \mathrm{~g}$, Monopotassium phosphate $1 \mathrm{~g}$, Dipotassium phosphate $1 \mathrm{~g}$, Ammonium nitrate $1 \mathrm{~g}$ and Ferric chloride $0.05 \mathrm{~g}$ in one litre) containing $2.5 \%$ of petrol [35]. These petri plates were incubated at $37^{\circ} \mathrm{C}$ for 24 hours. Among the developed colonies, one bacterial colony was selected for further studies.

The selected bacterial strain was subjected to Gram's staining and other biochemical tests like MR, VP, Indole, Catalase, Citrate, Gelatin liquefaction, Cellobiose, Lactose, Maltose, Sucrose, D-xylose, Trehalose, Sorbitol, Malonate, D-Arabinose and Glycerol utilization for identification adopting Bergey’s Manual [36].

For testing the biodegradation efficiency of the isolated bacterial strain, $100 \mathrm{ml}$ of minimal broth (Dextrose 1 g, Ammonium sulphate $1 \mathrm{~g}$, Dipotassium phosphate $0.7 \mathrm{~g}$, monopotassium phosphate $2 \mathrm{~g}$, Sodium citrate $0.5 \mathrm{~g}$, and Magnesium sulphate $0.1 \mathrm{~g}$ ) containing 2.5\%, 5\%, 7.5\% and 10\% petrol concentrations separately in $250 \mathrm{ml}$ Erlenmeyer flasks were prepared. To each flask, one $\mathrm{ml}$ inoculum from the pure culture of the isolated strain during the logarithmic phase was added. The culture flasks were incubated in a shaker at $30^{\circ} \mathrm{C}$ at $100 \mathrm{rpm}$. After 4, 8, 12 and 16 days of treatment, $\mathrm{pH}$, Optical density (OD) and $\mathrm{CO}_{2}$ were determined for each petrol concentration [37] [38].

The $\mathrm{pH}$ of the medium was estimated using a $\mathrm{pH}$ meter after every four days of treatment. The optical density of the culture medium was determined at $600 \mathrm{~nm}$ after $0,4,8,12$ and 16 days of treatment. For $\mathrm{CO}_{2}$ estimation one ml the culture medium was taken after 4, 8, 12 and 16 days of treatment from each petrol concentration and treated against $0.05 \mathrm{~N} \mathrm{NaOH}$ solution, the indicator used was phenolphthalein and the appearance of pink colour was the endpoint. Using the following formula the amount of $\mathrm{CO}_{2}$ was calculated [33].

$$
\mathrm{CO}_{2}(\mathrm{mg} / \mathrm{L})=\frac{\text { Titre value } \times \text { Normality of } \mathrm{NaOH} \times 1000 \times 44}{\text { Volume of the sample }}
$$

For HPLC analysis, fermented broth of the bacterial strain from $10 \%$ petrol concentration and the control were taken after 16 days of treatment and were administered for HPLC analysis at CECRI, Karaikudi (ModelShimadzn, Pump-LC-20 AD, PDA detector-SPDM 20A and Injection-20 $\mu$ l) [39]. The parameters pH, optical density and $\mathrm{CO}_{2}$ were subjected to two way analysis of variance (ANOVA) using MS Excel. Variations were 
considered statistically significant only when the calculated $\mathrm{F}$ value was greater than the tabulated $\mathrm{F}$ value at $\mathrm{P}$ is less than or equal the 0.05 [40].

\section{Results and Discussion}

Based on the biochemical tests, the isolated bacterial strain was identified as Pseudomonas aeruginosa. It was a gram negative rod exhibiting positive results to Citrate, Catalase, Gelatin liquefaction, Malonate and Glycerol tests. Negative results were observed for Gram reaction, Indole, Methyl Red (MR), Voges Proskauer (VP), Cellobiose, Lactose, Maltose, Sucrose, D-xylose, Trehalose, Sorbitol and D-Arabinose tests (Table 1).

Figure 1 divulges the changes in $\mathrm{pH}$ recorded after 4, 8, 12 and 16 days of treatment with Pseudomonas aeruginosa upto 8 days of treatment, decline in $\mathrm{pH}$ was observed in all the petrol concentration except $7.5 \%$ indicating the formation of organic acids after petrol degradation. After 8 days of treatment $\mathrm{pH}$ level was increased in all the petrol concentrations was noticed due to petrol degradation.

Changes in optical density during the treatment of petrol by Pseudomonas aeruginosa are illustrated in Figure 2. Increase in optical density values during the initial period of treatment was noticed. But afterwards, there was a decline and the maximum optical density was observed at $7.5 \%$ petrol concentration after eight days of treatment.

Figure 3 shows the changes in the $\mathrm{CO}_{2}$ level of the culture medium during the treatment of petrol by Pseudomonas aeruginosa. Petrol degradation resulted in the production of $\mathrm{CO}_{2}$ which showed a linear increase with the increase in petrol concentration. Highest level of $\mathrm{CO}_{2}$ was observed for $10 \%$ petrol after eight days of treatment. $\mathrm{CO}_{2}$ release showed on increase during initial period and later remained in the asymptote level except 5\% petrol concentration.

Table 1. Biochemical tests used for the identification of the isolated organism.

\begin{tabular}{|c|c|c|}
\hline Sample No & Biochemical Tests & Pseudomonas aeruginosa \\
\hline 1 & Colony character & \\
\hline 2 & Colony size & Medium \\
\hline 3 & Cell type & Rod \\
\hline 4 & Gram reaction & - \\
\hline 5 & MR test & - \\
\hline 6 & VP test & - \\
\hline 7 & Indole test & - \\
\hline 8 & Catalase test & + \\
\hline 9 & Citrate test & + \\
\hline 10 & Gelatin Liquefaction & + \\
\hline 11 & Cellobiose & - \\
\hline 12 & Lactose & - \\
\hline 13 & Maltose & - \\
\hline 14 & Sucrose & - \\
\hline 15 & D-xylose & - \\
\hline 16 & Trehalose & - \\
\hline 17 & Sorbitol & - \\
\hline 18 & Malonate & + \\
\hline 19 & D-Arabinose & - \\
\hline 20 & Glycerol & + \\
\hline
\end{tabular}

Note: + Positive; - Negative. 


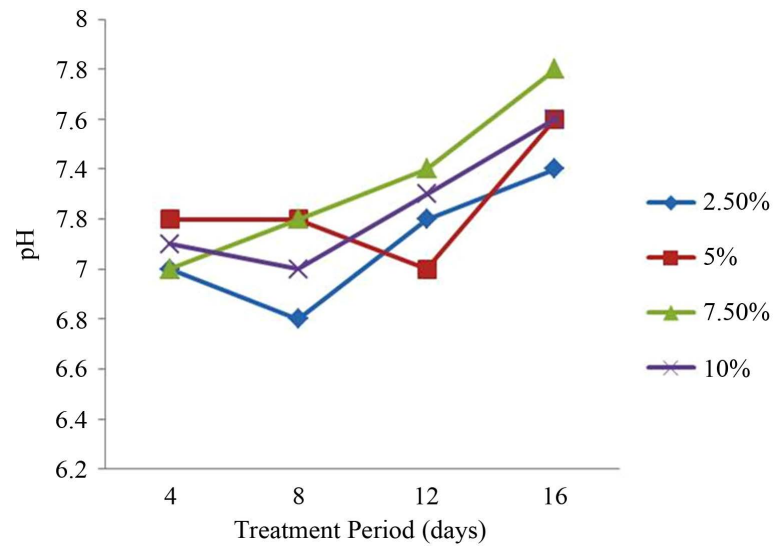

Figure 1. Changes in $\mathrm{pH}$ during the degradation of petrol by Pseudomonas aeruginosa.

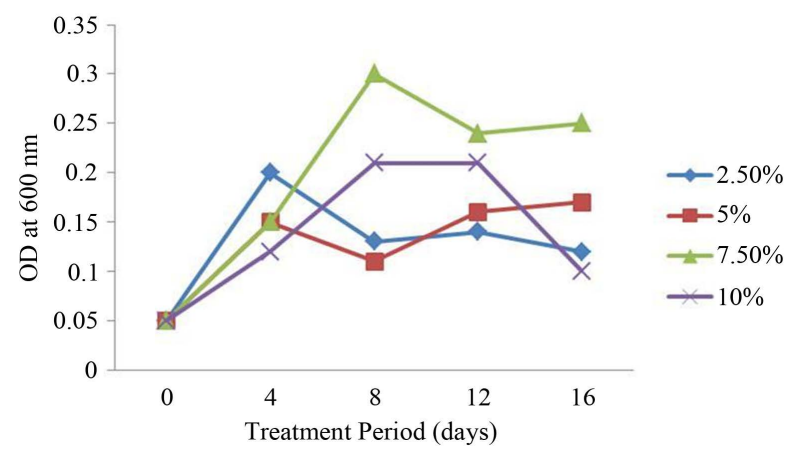

Figure 2. Optical Density of various concentrations of petrol during degradation by Pseudomonas aeruginosa.

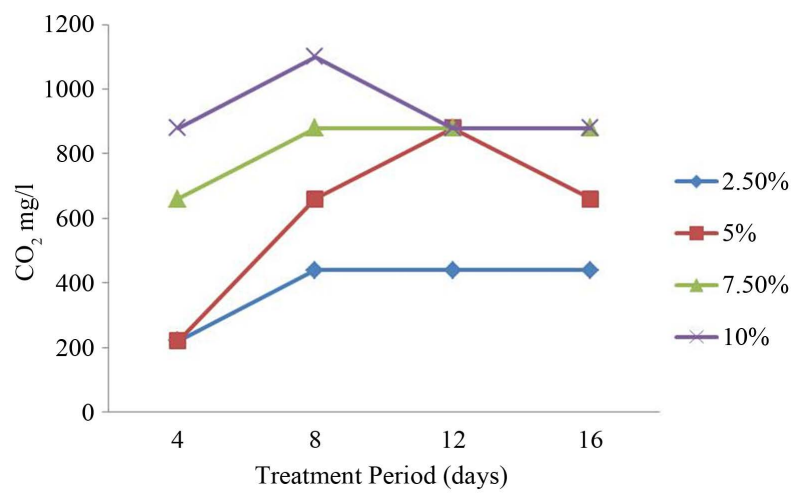

Figure 3. Carbondioxide released during degradation of petrol by Pseudomonas aeruginosa.

High Performance Liquid Chromatographic analysis report for control having $10 \%$ petrol concentration without inoculum is exhibited in Figure 4. In this, only two peaks were seen with the retention time of 1.933 and 2.247 minutes. Figure 5 illustrates the HPLC analysis report for $10 \%$ petrol concentration treated with Pseudomonas aeruginosa for sixteen days. In this, both the peaks observed in the control were missing but several new peaks with different retention time were appearing which indicated the degradation of petrol into several intermediates.

Table 2 divulges the two way analysis of variance for the parameters, $\mathrm{pH}$, optical density and $\mathrm{CO}_{2}$ with the variables treatment period and petrol concentration. Variations due to petrol concentration were statistically 
Table 2. Two way analysis of variance for the factors with the variables, treatment period and petrol concentration for $P$. aeruginosa.

\begin{tabular}{ccccccc}
\hline Factor & Source of variation & df & MS & Calculated F value & Table F value & Level of Significance \\
\hline \multirow{2}{*}{$\mathrm{pH}$} & Treatment period & 3 & 0.257 & 13.056 & 3.862548 & Significant \\
& Petrol concentration & 3 & 0.425 & 2.154 & 3.862548 & Not significant \\
\multirow{2}{*}{ Optical density } & Treatment period & 3 & 0.006 & 2.390 & 3.259167 & Not significant \\
& Petrol concentration & 3 & 0.013 & 5.448 & 3.862548 & Significant \\
\multirow{2}{*}{ Carbon dioxide } & Treatment period & 3 & 68566.67 & 4.636 & 3.862548 & Significant \\
& Petrol concentration & 3 & 237966.7 & 3.863 & 3.862548 & Significant \\
\hline
\end{tabular}

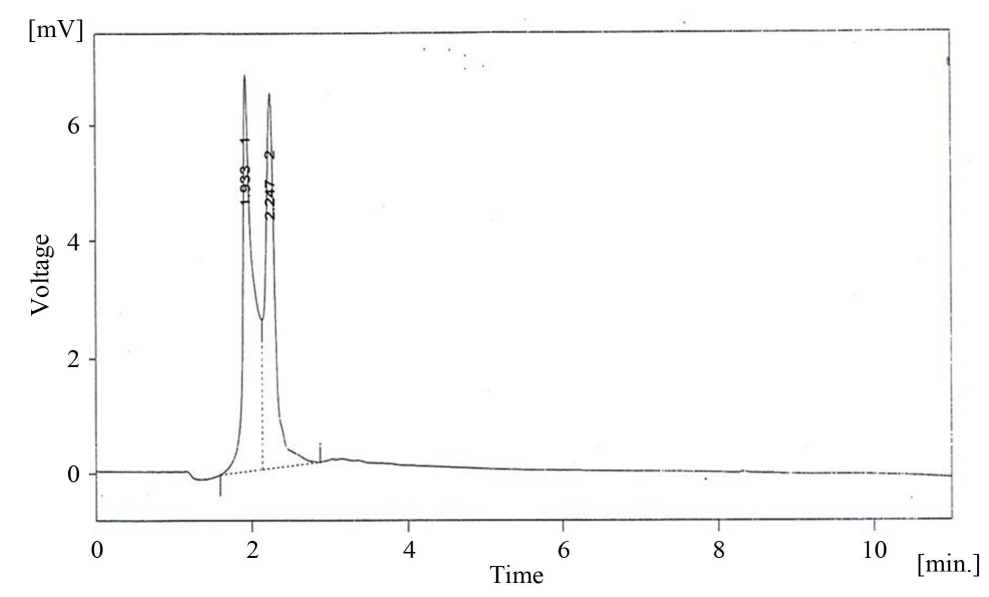

Figure 4. HPLC analysis report for $10 \%$ of Petrol (control).

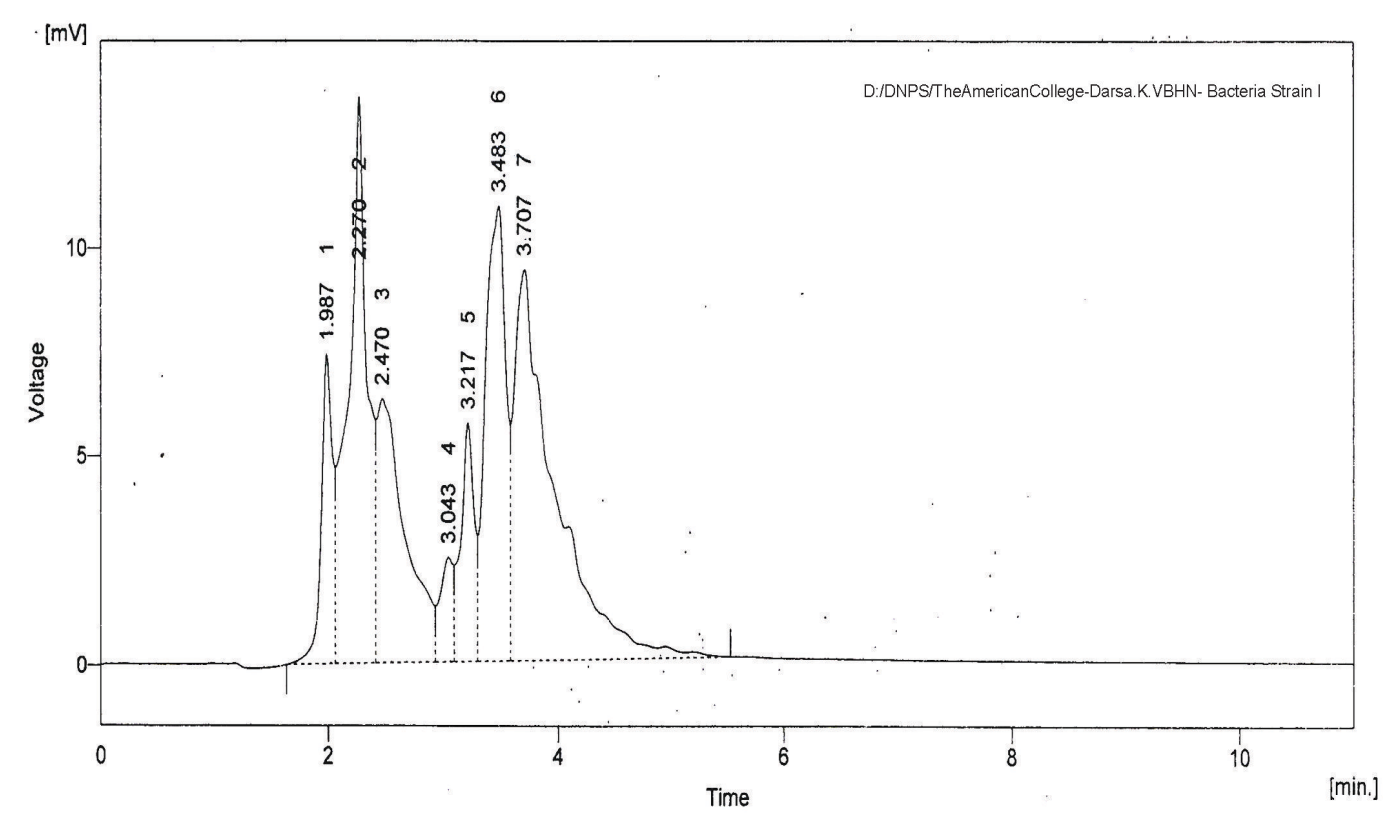

Figure 5. HPLC analysis report for $10 \%$ of Petrol treated with Pesudomonas aeruginosa for 16 days.

significant for optical density and $\mathrm{CO}_{2}$ while they were not statistically significant due to treatment period. Variations due to treatment period were significant for $\mathrm{pH}$, but they were not significant due to petrol concentration. 
The most rapid and complete degradation of the majority of organic pollutants is brought about under aerobic conditions [41]. The initial intracellular attack of organic pollutants is an oxidative process and the activation as well as incorporation of oxygen is the enzymatic key reaction catalyzed by oxygenases and peroxidases. Peripheral degradation pathways convert organic pollutants step by step into intermediates of the central intermediary metabolism, for example, the tricarboxylic acid cycle. Biosynthesis of cell biomass occurs from the central precursor metabolites, for example, acetyl-CoA, succinate and pyruvate. Sugars required for various biosyntheses and growth are synthesized by gluconeogenesis.

The microorganisms implicated in oil degradation are widely distributed in nature and have been isolated from soil and water with their oil degrading potentials [42]. The microbes capable of utilizing oil and oil products as a sole source of carbon and energy occur practically everywhere in air, water and soil [43]. It is estimated that in one gram of unpolluted soil, there are only 100 to 1,000 cells of hydrocarbon degrading microorganisms, whereas, in one gram of soil polluted by oil, their number increases to $1 \times 10^{6}$ to $5 \times 10^{7}$ cells, especially if pollution occurred repeatedly and for a long time [44]. Taxonomic charecteristics of these isolates identified them as Bacillus sp., Staphylococcus sp., Micrococcus sp., Pseudomonas sp., Psychrobacter sp., and Alcaligens faecalis [45]. Micrococcus, Staphylococcus, Pseudomonas putida and Alcaligenes were also reported to degrade diesel oil [46].

The rate of crude oil biodegradation in the soil was rapid and it might be due to the microorganisms in the soil having efficiency in utilizing the residual crude oil as a source of carbon and energy [47]. Crude oil contains hydrocarbon and does not resist attack by microorganisms. The hydrocarbon utilizing microorganisms isolated from the soil were species of Bacillus, Lactobacter, Arthrobacter, Pseudomonas, Micrococcus, Zoopage, and Articulosporium. Bacillus sp. predominated, especially in the crude oil polluted soil. This may be due to the ability of these organisms to produce spores, which may shield them from the toxic effects of the hydrocarbons [48].

However, bacterial degradation of oil is more significant (80\%) than fungi (20\%) [49] [50]. The genus Pseudomonas and Bacillus in particular have been the subject of numerous studies. The Pseudomonas sp is one of the best crude oil degraders. Pseudomonas is termed as Oil Eating Bug in crude oil industry. An interesting and useful characteristic of many Pseudomonas sp. is their ability to utilize a wide variety of organic substrates for growth. The bacterium invades the crude oil which consists of rich source of organic compounds suitable for the growth of this bacterium and produces biosurfactants that clean up the crude oil [51].

Pseudomonas aeruginosa exhibited the most excellent hexadecane-degrading ability at $\mathrm{pH}$ 7.0. Difference in the ability of Pseudomonas aeruginosa to biodegrade $n$-hexadecane at different $\mathrm{pH}$ values might be related not only to its role in the process of hydrocarbon metabolism, but also to its microbial diversity and activity under the acidic, neutral or alkaline conditions [52]. In this study $\mathrm{pH}$ showed an increase in all the concentrations and the highest $\mathrm{pH}$ was observed for $7.5 \%$ petrol concentration.

Microorganisms are considered to be efficient biodegraders due to their abundance, the wide variety of species, and their catabolic and anabolic versatility, as well as their ability to adapt to adverse environmental conditions. Through the metabolic activity of these microorganisms, organic pollutants can be transformed into water, $\mathrm{CO}_{2}$ and biomass [53].

The complete degradation of a compound to its mineral components, in which the organic carbon of the compound is converted to $\mathrm{CO}_{2}$ by respiration, is called mineralization. When the aerobic conditions are maintained, $\mathrm{CO}_{2}$ evolution can be used as a measure of microbial metabolic activity with reasonable accuracy [54]. Studies involving the measurement of the rate of mineralization can provide important information about the biodegradability of industrial waste compounds, including oil residues. In this study changes in $\mathrm{pH}, \mathrm{CO}_{2}$ and cell growth indirectly indicate the degradation of petrol.

The initial decline in $\mathrm{pH}$ may indicate the formation of organic acids as a result of petrol degradation by $P$. aeruginosa. The higher concentrations of petrol, during initial period of treatment exhibited an increase in biomass confirming the isolate being capable of exhibiting growth by breaking down petroleum hydrocarbons. This is also confirmed by the increased release of carbon dioxide which may be a product of petrol degradation. HPLC analysis also offers further confirmation exhibiting new peaks which represent the metabolites of petrol degradation.

The pattern of degradation showed that the microorganisms first attacked the lower and higher hydrocarbon chains and those of middle length were attacked later in the course of incubation. Considerable information on the microbial degradation is available in the literature, but less is known on the biodegradability of some petro- 
leum commercial products such as kerosene [55]. The dominant mechanism that breaks down these petroleum products is biodegradation, which is carried out by natural microbial population [56]. In the present study Pseudomonas aeruginosa is able to degrade petrol which is used as carbon and energy source.

\section{Conclusion}

The degradation of petrol by the isolate, Pseudomonas aeruginosa was found to be more efficient. This is evidenced by the changes in $\mathrm{pH}$, increase in optical density and $\mathrm{CO}_{2}$ released. Appearance of new peaks in the HPLC analysis confirms the degradation process. Thus, the isolate has the ability to tolerate the petrol concentrations and grow on them. Hence this strain can be employed as bioremediation agent and used in restoring the ecosystem contaminated with oil.

\section{Acknowledgements}

The authors thank the authorities of the American College for facilities and encouragement.

\section{References}

[1] Kvenvolden, K.A. and Cooper, C.K. (2003) Natural Seepage of Crude Oil into the Marine Environment. Geo-Marine Letters, 23, 140-146. http://dx.doi.org/10.1007/s00367-003-0135-0

[2] Mahvi, A.H. and Mardani, G. (2005) Determination of Phenanthrene in Urban Runoff of Tehran, Capital of Iran. Iranian Journal of Environmental Health, Science and Engineering, 2, 5-11.

[3] Mohan, S.V., Shailaja, S., Ramakrishna, M., Reddy, K. and Sarma, P. (2006) Bioslurry Phase Degradation of DEP Contaminated Soil in Periodic Discontinuous Mode Operation: Influence of Augmentation and Substrate Partition. Process Biochemistry, 41, 644-652. http://dx.doi.org/10.1016/j.procbio.2005.08.018

[4] Zhao, H., Wang, L., Ren, J., Li, Z., Li, M. and Gao, H. (2008) Isolation and Characterization of Phenanthrene-Degrading Strains Sphingomonas sp. ZP1 and Tistrella sp. ZP5. Journal of Hazardous Materials, 152, 1293-1300. http://dx.doi.org/10.1016/j.jhazmat.2007.08.008

[5] Surridge, A.K.J. (2007) Denaturing Gradient Gel Electrophoresis Characterisation of Microbial Communities in Polycyclic Aromatic Hydrocarbon and Polychlorinated Biphenyl Contaminated Soil. PhD Thesis, University of Pretoria, Pretoria.

[6] Ganjidoust, H. and Naghizadeh, G. (2005) Interaction's Effect of Organic Material and Aggregation on Extraction Efficiency of Tphs from Petroleum Contaminated Soils with MAE. Iran Journal of Environmental Health Science and Engineering, 2, 213-220. http://diglib.tums.ac.ir/pub/magmng/pdf/2566.pdf

[7] Samimi, S.V., Rad, R.A. and Ghanizadeh, F. (2009) Polycyclic Aromatic Hydrocarbon Contamination Levels in Collected Samples from Vicinity of a Highway. Iran Journal of Environmental Health Science and Engineering, 6, 47-52. http://dx.doi.org/10.1186/956727

[8] Delnavaz, M., Ayati, B. and Ganjidoust, H. (2008) Biodegradation of Aromatic Amine Compounds Using Moving Bed Biofilm Reactors. Iran Journal of Environmental Health Science and Engineering, 5, 243-250. http://ijehse.tums.ac.ir/files/journals/1/articles/176/public/176-177-1-PB.pdf

[9] Mohan, S.V., Prasanna, D., Reddy, B.P. and Sarma, P. (2008) Ex Situ Bioremediation of Pyrene Contaminated Soil in Bio-Slurry Phase Reactor Operated in Periodic Discontinuous Batch Mode: Influence of Bioaugmentation. International Biodeterioration and Biodegradation, 62, 162-169. http://dx.doi.org/10.1016/j.ibiod.2008.01.006

[10] Anastasi, A., Coppola, T., Prigione, V. and Varese, G. (2009) Short Communication: Pyrene Degradation and Detoxification in Soil by a Consortium of Basidiomycetes Isolated from Compost: Role of Laccases and Peroxidases. Journal of Hazardous Materials, 165, 1229-1233. http://dx.doi.org/10.1016/j.jhazmat.2008.10.032

[11] Larsen, S., Karakashev, D., Angelidaki, I. and Schmidt, J. (2009) Ex-Situ Bioremediation of Polycyclic Aromatic Hydrocarbons in Sewage Sludge. Journal of Hazardous Materials, 164, 1568-1572. http://dx.doi.org/10.1016/j.jhazmat.2008.08.067

[12] Muckian, L., Grant, R., Clipson, N. and Doyle, E. (2009) Bacterial Community Dynamics during Bioremediation of Phenanthrene- and Fluoranthene-Amended Soil. International Biodeterioration \& Biodegradation, 63, 52-56. http://dx.doi.org/10.1016/j.ibiod.2008.04.005

[13] Erdogan, E.E. and Karaca, A. (2011) Bioremediation of Crude Oil Polluted Soils. Asian Journal of Biotechnology, 3 , 206-213. http://dx.doi.org/10.3923/ajbkr.2011.206.213

[14] Keery, E. (1993) Bioremediation of Experimental Petroleum Spills in the Vestfold Hills, Antarctica. Polar Biology, 13, 163-170. 
[15] Ladousse, A. and Tramier, B. (1991) Results of 12 Years of Research in Spilled Oil Bioremediation. International Oil Spill Conference Proceedings, American Petroleum Institute, Washington, 1991, 577-581. http://dx.doi.org/10.7901/2169-3358-1991-1-577

[16] Leahy, J.G. and Colwell, R.R. (1990) Microbial Degradation of Hydrocarbons in the Environment. Microbiological Reviews, 54, 305-315. http://www.ncbi.nlm.nih.gov/pmc/articles/PMC372779/

[17] Nocentini, M., Pinelli, D. and Fava, F. (2000) Bioremediation of a Soil Contaminated by Hydrocarbon Mixtures: The Residual Concentration Problem. Chemosphere, 41, 1115-1123. http://dx.doi.org/10.1016/S0045-6535(00)00057-6

[18] Head, I.M., Jones, D.M. and Röling, W.F.M. (2006) Marine Microorganisms Make a Meal of Oil. Nature Reviews Microbiology, 4, 173-182. http://dx.doi.org/10.1038/nrmicro1348

[19] Da Cruz, F.G., De Vasconcellos, P.S., Angolini, F.F.C., Dellagnezze, M.B., Garcia, N.S.I., De Oliveira, M.V., Neto, S.D.V.E. and Marsaioli, A.J. (2011) Could Petroleum Biodegradation Be a Joint Achievement of Aerobic and Anaerobic Microorganisms in Deep Sea Reservoirs? AMB Express, 1, 47. http://dx.doi.org/10.1186/2191-0855-1-47

[20] Oliveira, P.L.F., Vasconcellos, S.P., Angolini, C.F.F., da Cruz, G.F., Marsaioli, A.J., Neto, E.V.S. and Oliviera, V.M. (2012) Taxonomic Diversity and Biodegradation Potentialof Bacteria Isolated from Oil Reservoirs of an Offshore Southern Brazilian Basin. Journal of Petroleum and Environmental Biotechnology, 3, 132.

[21] Oh, Y.S., Sim, D.S. and Kim, S.J. (2001) Effects of Nutrients on Crude Oil Biodegradation in the Upper Intertidal Zone. Marine Pollution Bulletin, 42, 1367-1372. http://dx.doi.org/10.1016/S0025-326X(01)00166-7

[22] Berwick, P.G. (2004) Physical and Chemical Conditions for Microbial Oil Degradation. Biotechnology and Bioengineering, 26, 1294-1305. http://dx.doi.org/10.1002/bit.260261106

[23] Xu, R., Yong, L.C., Lim, Y.G. and Obbard, J.P. (2005) Use of Slow-Release Fertilizer and Biopolymers for Stimulating Hydrocarbon Biodegradation in Oil-Contaminated Beach Sediments. Marine Pollution Bulletin, 51, 1101-1110. http://dx.doi.org/10.1016/j.marpolbul.2005.02.037

[24] Toledo, F.L., Calvo, C., Rodelas, B. and Gonzdlezlopez, J. (2006) Selection and Identification of Bacteria Isolated from Waste Crude Oil with Polycyclic Aromatic Hydrocarbons Removal Capabilities. Systematic and Applied Microbiology, 29, 244-252. http://dx.doi.org/10.1016/j.syapm.2005.09.003

[25] Song, R., Hua, Z., Li, H. and Chen, J. (2006) Biodegradation of Petroleum Hydrocarbons by Two Pseudomonas aeruginosa Strains with Different Uptake Modes. Journal of Environmental Science and Health, Part A: Toxic/Hazardous Substances and Environmental Engineering, 41, 733-748. http://dx.doi.org/10.1080/10934520600575135

[26] Ueno, A., Ito, Y., Yamamoto, Y., Yumoto, I. and Okuyama, H. (2006) Bacterial Community Changes in Diesel-OilContaminated Soil Microcosms Stimulation with Luria-Bertani Medium or Bioaugmintation with Petroleum-Degrading Bacterium, Pseudomonas aeruginosa Strain WatG. Journal of Basic Microbiology, 46, 310-317. http://dx.doi.org/10.1002/jobm.200510116

[27] Das, K. and Mukherjee, A.K. (2007) Crude Petroleum-Oil Biodegradation Efficiency of Bacillus subtilis and Pseudomonas aeruginosa Strains Isolated from Petroleum-Oil Contaminated Soil from North-East India. Bioresource Technology, 98, 1339-1345. http://dx.doi.org/10.1016/j.biortech.2006.05.032

[28] Mittal, A. and Singh, A. (2009) Isolation of Hydrocarbon Degrading Bacteria from Soil Contaminated with Crude Oil Spills. Indian Journal of Experimental Biology, 47, 760-765. http://nopr.niscair.res.in/handle/123456789/5981

[29] Verma, S., Saxena, J., Prasanna, R., Sharma, V. and Nain, L. (2012) Medium Optimization for a Novel Crude-Oil Degrading Lipase from Pseudomonas aeruginosa SL-72 Using Statistical Approaches for Bioremediation of Crude-Oil. Biocatalysis and Agricultural Biotechnology, 1, 321-329. http://dx.doi.org/10.1016/j.bcab.2012.07.002

[30] Zobell, C.E. (1946) Action of Microorganisms on Hydrocarbons. Bacteriological Review, 10, 1-49. http://www.ncbi.nlm.nih.gov/pmc/articles/PMC440899/pdf/bactrev00176-0004.pdf

[31] Texas Research Institute, Inc. (1982) Enhancing the Microbial Degradation of Underground Gasoline by Increasing Available Oxygen. Report to the American Petroleum Institute, Washington.

[32] Englert, C.J., Kenzie, E.J. and Dragun, J. (1993) Bioremediation of Petroleum Products in Soil. In: Calabrese, E.J. and Kostecki, P.T., Eds., Principles and Practices for Petroleum Contaminated Soils, Lewis Publishers, Chelsea, MI, 111130.

[33] APHA-AWWA-WEF (1995) Standard Methods for the Examination of Water and Wastewater. 19th Edition, Washington DC.

[34] Waksman, S.A. (1922) A Method of Counting the Number of Fungi in Soil. Journal of Microbiology, 7, 339-341. http://www.ncbi.nlm.nih.gov/pmc/articles/PMC378974/pdf/jbacter01062-0041.pdf

[35] Bushnell, L.D. and Haas, H.F. (1941) The Utilization of Certain Hydrocarbons by Microorganisms. Journal of Bacteriology, 41, 653. http://www.ncbi.nlm.nih.gov/pmc/articles/PMC374727/pdf/jbacter00729-0101.pdf

[36] Holt, J.G., Krieg, N.R., Sneath, P.H.A., Staley, J.T. and Williams, S.T. (1994) Bergey’s Manual of Determinative Bac- 
teriology. 9th Edition, Williams \& Wilkins, Baltimore.

[37] Plummer, M.U. and Plummer, D.T. (1988) Introduction to Practical Biochemistry. Tata McGraw-Hill Education, Noida.

[38] Cappuccino, J.G. and Sherman, N. (2001) Microbiology: A Laboratory Manual. 6th Edition, Benjamin Cummings, San Francisco.

[39] Vidhya, R. and Thatheyus, A.J. (2013) Biodegradation of Dimethylformamide Using Bacillus subtilis. American Journal of Microbiological Research, 1, 10-15. http://dx.doi.org/10.12691/ajmr-1-1-3

[40] Zar, J.H. (2010) Biostatistical Analysis. Prentice Hall, Upper Saddle River, 944.

[41] Fritsche, W. and Hofrichter, M. (2000) Aerobic Degradation by Microorganisms. In: Klein, J., Ed, Environmental Processes-Soil Decontamination, Wiley-VCH, Weinheim, 146-155.

[42] Bello, Y.M. (2007) Biodegradation of Lagoma Crude Oil Using Pig Dung. African Journal of Biotechnology, 6, 28212825.

[43] Oliver, B. and Magot, M. (2005) Indigenous Microbial Communities in Oil Fields. In: Petroleum Microbiol, ASM Press, Washington DC, 21-34.

[44] Rosenberg, E.R. (1996) Bioremediation of Petroleum Contamination. In: Crawford, R.L. and Crawford, D.L., Eds., Bioremediation: Principles and Applications, Cambridge University Press, Cambridge, 100-124. http://dx.doi.org/10.1017/CBO9780511608414.006

[45] Sathishkumar, M., Binupriya, A.R., Baik, S.H. and Yun, S.E. (2008) Biodegradation of Crude Oil by Individual Bacterial Strains and a Mixed Bacterial Consortium Isolated from Hydrocarbon Contaminated Areas. Clean, 36, 92-96.

[46] Pepi, M., Minacci, A., Di Cello, F., Baldi, F. and Fani, R. (2003) Long-Term Analysis of Diesel Fuel Consumption in a Co-Culture of Acinetobacter venetianus, Pseudomonas putida and Alcaligenes faecalis. Antonie van Leeuwenhoek, 83, 3-9. http://www.ncbi.nlm.nih.gov/pubmed/12755474 http://dx.doi.org/10.1023/A:1022930421705

[47] Antai, S.P. (1990) Biodegradation of Bonny Light Crude Oil by Bacillus sp. and Pseudomonas sp. Waste Management, 10, 61-64. http://dx.doi.org/10.1016/0956-053X(90)90070-2

[48] Onifade, A.K. and Abubakar, F.A. (2007) Characterization of Hydrocarbon-Degrading Microorganisms Isolated from Crude Oil Contaminated Soil and Remediation of the Soil by Enhanced Natural Attenuation. Research Journal of Biological Sciences, 2, 36-40. http://medwelljournals.com/abstract/?doi=rjbsci.2007.36.40

[49] Hamme, J.D.V. (1999) Influences of Chemical Surfactants on the Biodegradation of Crude Oil by a Mixed Bacterial Culture. Canadian Journal of Microbiology, 45, 130-137. http://www.nrcresearchpress.com/doi/pdf/10.1139/w98-209 http://dx.doi.org/10.1139/w98-209

[50] Leathy, J.G. and Colwell, R.R. (1990) Microbial Degradation of Hydrocarbons in the Environment. Microbiological Reviews, 54, 305-315. http://www.ncbi.nlm.nih.gov/pmc/articles/PMC372779/

[51] Kilbane, J., Ranganathan, R., Cleveland, L., Kayser, K.J., Ribiero, C. and Linhares, M.M. (2000) Selective Removal of Nitrogen from Quinoline and Petroleum by Pseudomonas ayucida IGTN 9M. Applied and Environmental Microbiology, 66, 688-693. http://www.ncbi.nlm.nih.gov/pmc/articles/PMC91882/pdf/am000688.pdf http://dx.doi.org/10.1128/AEM.66.2.688-693.2000

[52] Boshui, C., Nan, Z., Jiang, W., Jiu, W. and Jianhua, F. (2012) Biodegradation of Petroleum Hydrocarbon by Pseudomonas Aeruginosa. China Petroleum Processing and Petrochemical Technology, 14, 66-70. http://www.chinarefining.com/EN/volumn/volumn 1145 abs.shtml

[53] Genow, G., Naeyer, F., Van Meenen, P., Van de Werf, H., Nijs, W. and Verstraete, W. (1994) Degradation of Oil Sludge by Landfarming-A Case-Study at the Ghent Harbor. Biodegradation, 5, 37-46.

[54] Atlas, R.M. (1992) Oil Spills: Regulation and Biotechnology: Guest Editorial. Current Opinion in Biotechnology, 3, 220-223. http://dx.doi.org/10.1016/0958-1669(92)90095-Z

[55] Wongsa, P., Tanaka, M., Ueno, A., Hasanuzzaman, M., Yumoto, I. and Okuyama, H. (2004) Isolation and Characterization of Novel Strains of Pseudomonas aeruginosa and Serratia marcescens Possessing High Efficiency to Degrade Gasoline, Kerosene, Diesel Oil, and Lubricating Oil. Current Microbiology, 49, 415-422. http://dx.doi.org/10.1007/s00284-004-4347-y

[56] Margesin, R. and Schinner, F. (2001) Biodegradation and Bioremediation of Hydrocarbons in Extreme Environments. Applied Microbiology and Biotechnology, 56, 650-663. http://dx.doi.org/10.1007/s002530100701 